\title{
Upaya Meningkatkan Keterampilan Menulis Siswa melalui Penerapan Metode Think Pair Share
}

\author{
Mutatik $^{(1)}$ \\ ${ }^{1}$ SMPN 1 Besuki, Tulungagung \\ Email: ${ }^{1}$ mutatik@gmail.com, \\ DOI: https://doi.org/10.28926/riset_konseptual.v2i2.46
}

\begin{abstract}
ABSTRAK
Berdasarkan hasil observasi yang dilakukan di Kelas IX A pada waktu pembelajaran Bahasa Indonesia diperoleh hasil bahwa Ketrampilan Menulis siswa kurang memuaskan. Untuk meningkatkan Ketrampilan Menulis Bahasa Indonesia yang memuat Menulis Iklan Baris pada Siswa Kelas IX A SMP Negeri 1 Besuki Tulungagung, Peneliti melakukan penelitian tindakan kelas dengan menerapkan pendekatan Think Pair Share pada pembelajaran Bahasa Indonesia. Sasaran penelitian ini adalah siswa Kelas IX A SMP Negeri 1 Besuki Tulungagung yang berjumlah 30 siswa. pendekatan Think Pair Share dapat meningkatkan Ketrampilan Menulis siswa.
\end{abstract}

Kata kunci: ketrampilan menulis, think pair share,

\section{PENDAHULUAN}

Menulis sangat penting bagi pendidikan karena memudahkan para pelajar berpikir. Juga dapat menolong kita berpikir kritis, dapat memudahakan kita merasakan dan menikmati hubungan-hubungan, memperdaya daya tanggap atau persepsi kita. Tidak jarang, kita menemui apa yang sebenarnya kita pikirkan dan rasakan mengenai orang-orang, gagasan-gagasan, masalah-masalah, dan kejadian -kejadian hanya dalam proses menulis yang aktual. Menulis adalah suatu bentuk berpikir bagi waktu tertentu. Henry Guntur Tarigan (1986: 15) menyatakan bahwa menulis dapat diartikan sebagai kegiatan menuangkan ide/gagasan dengan menggunakan bahasa tulis sebagai media penyampai.

Pelajaran Bahasa Indonesia terdapat kompetensi dasar menulis iklan baris dengan bahasa yang singkat, padat, dan jelas. Tujuan pembelajaran tersebut adalah siswa dapat mendaftar butir-butir yang akan dituliskan dalam iklan baris di surat kabar dan dapat menulis iklan baris dengan bahasa yang hemat. Indikator keberhasilannya yang diharapkan adalah (1) Mampu menentukan objek yang akan diiklankan; (2) Mampu menyingkat kata-kata sesuai dengan kebiasaan iklan baris; (3) Mampu menulis iklan baris dengan bahasa yang singkat, padat, dan jelas; (4) Mampu menyunting iklan baris

Dari informasi yang di peroleh dari guru Bahasa Indonesia di SMP Negeri 1 Besuki, pembelajaran Bahasa Indonesia yang selama ini sudah dilaksanakan di SMP Negeri 1 Besuki menggunakan Metode ceramah yang terkadang diselingi dengan diskusi kelompok (pembelajaran kooperatif) dan masih menerapkan keaktifan guru dalam kegiatan pembelajarannya. Pembelajaran cenderung bersifat informatif sehingga keterlibatan siswa secara aktif dalam proses pembelajaran masih kurang. Kondisi yang demikian akan membuat siswa kurang termotivasi untuk belajar. Hal ini terbukti dengan perilaku siswa yang kurang bersemangat dalam mengikuti kegiatan belajar di kelas sehingga nilai siswa pada mata pelajaran Bahasa Indonesia kurang memuaskan. Agar tujuan pembelajaran Bahasa Indonesia di SMP dapat dicapai maka perlu adanya inovasi dalam proses pembelajaran Bahasa Indonesia di kelas. Inovasi tersebut dapat berupa model pembelajaran yang bisa membuat siswa menjadi lebih aktif dan bersemangat dalam melakukan proses pembelajaran. 
Menulis merupakan salah satu materi yang di ajarkan di bangku sekolah. Adapun tujuan pembelajaran ini dapat kita tinjau dari dua sudut pandang, untuk para siswa ditujukan agar para siswa mampu menghayati bahasa dan juga sastra Indonesia serta mempunyai kemampuan yang baik dan benar dalam berbahasa. Sementara tujuan bagi para guru yaitu untuk mengembangkan potensi para siswa dalam berbahasa Indonesia, serta agar lebih mandiri dalam menyiapkan dan menentukan bahan ajar sesuai dengan kemampuan siswa dan kondisi lingkungan.

Selain itu, yang menjadi tujuan umum dari pembelajaran suatu Bahasa yakni peran pentingnya di dalam perkembangan intelektual dan emosional siswa serta sebagai penunjang keberhasilan dalam mempelajari semua mata pelajaran. Di samping itu pembelajaran Bahasa Indonesia juga dapat memungkinkan manusia untuk bisa saling berkomunikasi dan berbagi pengalaman serta saling belajar satu sama lain untuk meningkatkan kemampuan intelektual.

Dengan pembelajaran bahasa Indonesia agar siswa diharapkan memiliki kemampuan sebagai berikut (1) Siswa diharapkan mampu menggunakan bahasa Indonesia secara baik dan benar serta dapat berkomunikasi secara efektif dan efisien baik secara lisan maupun tulis sesuai dengan etika yang berlaku. (2) Siswa bangga dan menghargai bahasa Indonesia sebagai bahasa negara dan bahasa pemersatu bangsa Indonesia. (3) Siswa mampu memahami bahasa Indonesia serta dapat menggunakannya dengan tepat dan kreatif untuk berbagai tujuan. (4) Siswa mampu menggunakan bahasa Indonesia untuk meningkatkan kemampuan intelektual, serta kematangan emosional dan sosial. (5) Siswa dapat membaca dan memanfaatkan karya sastra untuk memperluas wawasan, memperhalus budi pekerti, serta meningkatkan pengetahuan dan kemampuan berbahasa. (6) Siswa diharapkan dapat menghayati bahasa dan sastra Indonesia serta menghargai dan bangga terhadap sastra Indonesia sebagai khazanah budaya dan intelektual Indonesia.

Menulis iklan baris termasuk keterampilan berbahasa yang harus diajarkan pada mata pelajaran bahasa Indonesia. Diangkatnya kompetensi dasar tersebut karena siswa merasa kesulitan pada saat menentukan objek yang akan diiklankan, dan ketika menulis iklan baris dengan bahasa yang singkat, padat, dan jelas kurang sesuai dengan ketentuan.

Untuk memperbaiki pembelajaran menulis dan meningkatkan kemampuan siswa dalam menulis iklan baris, peneliti merasa tertarik untuk melakukan penelitian. Peneliti mencoba untuk menerapkan pembelajaran menulis khususnya menulis teks iklan baris di surat kabar melalui metode think pair share.

Memahami betul butir-butir pokok apa yang harus ada dalam iklan baris. Yaitu (1) Hal-hal yang harus diperhatikan dalam menulis iklan baris. (2) Pernyataan yang ditulis harus singkat. (3) Pernyataan harus jelas sehingga informasi yang disampaikan dapat dipahami calon konsumen. (4) Pernyataan hendaknya menarik sehingga mampu menjadi daya pikat.

Berdasarkan hasil pengamatan dalam proses belajar mengajar dikelas, keadaan sekolah, dan melalui peninjauan bidang akademik dan non akademik, diperoleh hasil bahwa keadaan Sekolah Menengah Pertama Negeri 1 Besuki khususnya siswa Kelas IX A tahun ajaran 2015/2016 dalam pelajaran Bahasa Indonesia belum menunjukkan Ketrampilan Menulis sesuai dengan KKM yang ditetapkan terutama pada materi pelajaran Menulis Iklan Baris. Padahal, ditinjau dari keadaan fisik sekolah, yaitu ruang Kelas IX A sudah baik dan sesuai sebagai tempat berlangsungnya proses belajar mengajar. Pengamatan pada proses pembelajaran oleh peneliti dapat disimpulkan bahwa pelaksanaan proses belajar mengajar lah yang belum membuat siswa aktif belajar, sehingga kemampuan siswa belum tergali dengan maksimal.

Pada ulangan harian Bahasa Indonesia dengan materi Menulis Iklan Baris, di dapat rata-rata nilai sebesar 65,2 dari 30 siswa, padahal Kriteria Ketuntasan Minimalnya (KKM) telah ditentukan nilai sebesar 70. Dan hanya 10 siswa yang 
mendapat nilai di atas 70 . Hal ini berarti, hanya $33,3 \%$ dari siswa yang telah mencapai ketuntasan belajar, dan yang lainnya memiliki Ketrampilan Menulis yang rendah.

Dari hasil diskusi dengan teman sejawat ditemukan masalah-masalah dalam proses pembelajaran Bahasa Indonesia yang menyebabkan menurunkan Ketrampilan Menulis adalah materi kurang dapat dikuasi siswa secara optimal, penggunaan pendekatan pembelajaran dalam pembelajaran Bahasa Indonesia pada siswa Kelas IX A belum sesuai, siswa terlihat tidak antusias untuk belajar dan pembelajaran dengan pendekatan konvensional yaitu dengan menjelaskan materi dan siswa hanya melakukan perintah mengerjakan soal tanpa penanaman konsep pembelajaran yang kuat terlihat tidak efektif dalam proses peningkatan Ketrampilan Menulis siswa.

Oleh karena itu, demi memperbaiki berbagai masalah yang ada, peneliti memerlukan suatu solusi untuk mengatasi hambatan-hambatan yang terjadi, peneliti menggunakan pendekatan Think Pair Share dalam pembelajaran Bahasa Indonesia ini. Strategi Think Pair Share dimaksudkan sebagai alternatif terhadap struktur kelas tradisional seperti resitasi, dimana guru mengajukan pertanyaan kepada seluruh siswa dan siswa memberikan jawaban setelah mengangkat tangan dan ditunjuk. Strategi ini menantang asumsi bahwa seluruh resitasi dan diskusi perlu dilakukan di dalam lingkungan seluruh kelompok.

Think-Pair-Share adalah pembelajaran dengan cara siswa saling belajar satu sama lain dan mendapatkan jalan keluar dari ide mereka setelah berdiskusi dan membuat ide mereka untuk didiskusikan dalam seluruh kelas (Gunter, 1999).

Think Pair Share digunakan untuk mengajarkan isi akademik atau untuk mengecek pemahaman siswa terhadap isi tertentu. Guru menciptakan interaksi yang dapat mendorong rasa ingin tahu, ingin mencoba, bersikap mandiri, dan ingin maju. Guru memberi informasi, hanya informasi yang mendasar saja, sebagai dasar pijakan bagi anak didik dalam mencari dan menemukan sendiri informasi lainnya. Atau guru menjelaskan materi dengan mengaitkannya dengan pengalaman dan pengetahuan anak sehingga memudahkan mereka menanggapi dan memahami pengalaman yang baru bahkan membuat anak didik mudah memusatkan perhatian. Karenanya guru sangat perlu memperhatikan pengalaman dan pengetahuan anak didik yang didapatinya dalam kehidupan sehari-hari.

Sedangkan tujuan model pembelajaran tipe Think-Pair-Share menurut gunter antara lain sebagai berikut (1) Menciptakan intraksi yang mendorong rasa ingin tahu, mencoba, dan ingin maju pada siswa. (2) Menjadikan proses belajar mengajar yang aktif, kreatif, efektif dan menyenangkan. (3) Menjadikan pembelajaran yang berpusat pada siswa. (4) Menciptakan keterampilan-keterampilan sosial meliputi kerjasama, tenggang rasa, tolong menolong.

\section{METODE}

Lokasi yang digunakan tempat penelitian adalah ruang Kelas IX A Sekolah Menengah Pertama Negeri 1 Besuki Kecamatan Besuki Kabupaten Tulungagung Tahun Pelajaran 2015/2016. Dalam penelitian ini subjek yang digunakan adalah seluruh siswa Kelas IX A Sekolah Menengah Pertama Negeri 1 Besuki Kecamatan Besuki Kabupaten Tulungagung sebanyak 30 siswa yang terdiri dari 18 siswa putra dan 12 siswa putri.

Penelitian dilaksanakan pada semester 1, adapun pada siklus pertama dilaksanakan pada hari Kamis, 17 September 2015 dan siklus kedua dilaksanakan pada hari Kamis, 24 September 2015.

Penelitian ini menggunakan pendekatan penelitian kualitatif dengan pendekatan penelitian tindakan kelas karena penelitian ini dilaksanakan berdasarkan adanya temuan masalah di kelas. Berdasarkan variable yang diteliti dan tujuan yang hendak dicapai, maka pendekatan penelitian yang digunakan adalah dengan sistem spiral. Stephen Kemmis dan Robin Mc Taggart tahun 1988 mengembangkan model Kurt Lewin dalam suatu sistem spiral dengan empat komponen utama, yakni perencanaan (planning), tindakan (acting), observasi (observing) dan refleksi 
(reflecting). Tahap pelaksanaan tindakan yaitu merupakan suatu hal yang dilakukan sebagai upaya perubahan yang dilakukan. Tahap observasi atau pengamatan yaitu mengamati secara sistematis hasil atau dampak tindakan terhadap proses belajarmengajar, dan tahap refleksi yaitu mengkaji dan mempertimbangkan hasil atau dampak tindakan yang dilakukan.

Peneliti dalam penelitian kualitatif berperan sebagai instrument penelitian, kehadiran peneliti mutlak diperlukan, dalam hal ini peneliti bertindak sebagai perencana, pelaksanaan pengajaran, pengumpul data, penganalisis, penafsir dan sebagai pelapor hasil penelitian. Peneliti berkolaborasi dengan teman sejawat sebagai observer. Penelitian ini bertempat di SMP Negeri 1 Besuki Kabupaten Tulungagung. SMP Negeri 1 Besuki ini termasuk lembaga pendidikan yang memiliki hasil output bagus dilingkup sekitarnya. Namun terlihat nilai pembelajaran Bahasa Indonesia di Kelas IX A belum maksimal, Guru lebih banyak berceramah, siswa hanya sebagai pendengar, kondisi seperti ini mengakibatkan siswa merasa bosan dan enggan belajar Bahasa Indonesia dan susah dalam mengerjakan soal-soal Bahasa Indonesia khususnya Menulis Iklan Baris. Selain itu, dilihat bahwa nilai Bahasa Indonesia siswa masih belum menggembirakan karena masih terdapat siswa yang nilainya berada di bawah KKM. Dalam pelaksanaan Penelitian Perbaikan Pembelajaran ini yang akan menjadi subjek adalah Siswa Kelas IX A SMP Negeri 1 Besuki Tulungagung, yang berjumlah 30 siswa.

Berdasarkan hasil pengidentifikasian dan penetapan masalah, peneliti kemudian mengajukan suatu solusi yang berupa penerapan Pendekatan Think Pair Share yang dapat dimanfaatkan Guru untuk digunakan sebagai pendekatan pengajaran dalam pembelajaran Bahasa Indonesia Kelas IX A SMP Negeri 1 Besuki Kecamatan Besuki Tulungagung. Penelitian ini dilakukan dengan dua siklus, dimana masing-masing siklus dikenai perlakuan yang sejenis dengan bobot yang beda. Dibuat dua siklus dimaksudkan untuk memperbaiki system pengajaran yang dilaksanakan.. Pelaksanaan tindakan pada siklus 1 dan siklus 2 dibagi menjadi 4 tahapan yaitu (1) Persiapan awal, (2) pertemuan awal, (3) proses supervisi (observasi), dan (4) pertemuan balikan atau refkleksi.

Pengumpulan data dalam penelitian ini dapat dilakukan dengan menggunakan teknik observasi, angket, dokumentasi, tes, wawancara, dan catatan lapangan. Teknik analisis data yang digunakan dalam penelitian ini adalah teknik analisis data kualitatif yaitu menggambarkan kenyataan atau data sesuai dengan data yang diperoleh dengan tujuan untuk mengetahui peningkatan kualitas kinerja guru. Langkah-langkah analisis terdiri dari tiga alur kegiatan yang terjadi secara bersamaan yaitu: (1) reduksi data, (2) penyajian data, (3) penarikan kesimpulan.

Pada kegiatan reduksi data, peneliti mengumpulkan pelaksanaan pengembangan pembelajaran menggunakan pendekatan Think Pair Share dan Ketrampilan Menulis siswa Data hasil reduksi yaitu pelaksanaan pengembangan pembelajaran menggunakan pendekatan Think Pair Share pada siklus 1 dan 2, data hasil observasi Guru pada siklus 1 dan siklus 2. Kegiatan penyajian data dilakukan dalam rangka mengorganisasikan hasil reduksi, dengan menyusun secara narasi sekumpulan informasi yang diperoleh dari hasil reduksi hingga memberi kemungkinan adanya penarikan kesimpulan dan pengambilan tindakan. Informasi yang dimaksud adalah apakah penerapan pendekatan Think Pair Share dapat meningkatkan Ketrampilan Menulis siswa, Pengelolaan pembelajaran oleh Guru, respon siswa terhadap kegiatan pembelajaran, serta hasil yang diperoleh sebagai akibat dari pemberian tindakan. Sajian data selanjutnya ditafsirkan dan dievaluasi untuk merencanakan tindakan selanjutnya.

Teknik analisis yang digunakan yaitu deskriptif persentase. Data hasil penelitian yang dianalisis meliputi rata-rata kelas, ketuntasan belajar individu dan ketuntasan belajar secara klasikal. Selanjutnya hasil analisis data diperoleh baik secara kualitatif (dengan kata-kata) dan kuantitatif (dengan grafik). Hasil ini diinterprestasikan dan disimpulkan untuk menjawab permasalahan yang ada 
Vol. 2 No. 2, April 2018;

Kegiatan penarikan kesimpulan mencakup pencarian arti dan makna data serta memberi penjelasan. Makna dan arti yang diperoleh tersebut harus di uji kebenarannya serta kecocokannya melalui kegiatan verifikasi. Verifikasi tersebut merupakan validitas data yang disimpulkan. Hasil analisis data ini akan dijadikan dasar untuk menentukan keberhasilan pemberian tindakan. Selain itu analisis data ini akan digunakan dasar untuk melaksanakan tindakan selanjutnya, jika pemberian tindakan sebelumnya tidak berhasil. Berdasarkan analisis maka akan ditentukan mana yang perlu dilakukan perbaikan untuk pelaksanaan tindakan selanjutnya. Penarikan kesimpulan dilihat dari hasil ketuntasan belajar siswa baik secara individu maupun kelompok selama pembelajaran dengan menggunakan pengembangan pendekatan Think Pair Share.

Patokan penilaian yang digunakan adalah target indikator pencapaian persentase target ketercapaian pada indikator yang ditetapkan dalam penelitian ini berdasarkan pada hasil observasi yang dilakukan baik pra siklus, siklus 1 ataupun siklus 2, dikatakan indikator tercapai bila $85 \%$ dari siswa Kelas IX A mendapat nilai Bahasa Indonesia minimal di atas KKM atau 70

Evaluasi dilaksanakan setelah diperoleh hasil analisis yang akurat. Kegiatan evaluasi dilakukan untuk mengetahui keberhasilan penelitian dalam meningkatkan Ketrampilan Menulis siswa melalui pembelajaran menggunakan pendekatan Think Pair Share pada pembelajaran Bahasa Indonesia materi Menulis Iklan Baris, jika hasil penelitian belum sesuai dengan harapan, maka akan dicari penyebabnya. Untuk itu dalam penelitian juga diperlukan refleksi. Refleksi merupakan kegiatan memikirkan atau merenungkan kembali semua kegiatan yang telah dilakukan, kemudian mencari solusi perbaikan yang dapat dilakukan untuk meningkatkan keberhasilan tindakan yang dilakukan.

\section{HASIL \\ Pra Siklus}

Sebelum melaksanakan proses penelitian, peneliti mengumpulkan data dan informasi tentang subjek penelitian. Data-data yang dikumpulkan antara lain daftar nama siswa Kelas IX A, daftar nilai ulangan harian Bahasa Indonesia materi Menulis Iklan Baris, hasil wawancara dengan informan yaitu siswa Kelas IX A SMP Negeri 1 Besuki Kecamatan Besuki Kabupaten Tulungagung. Dari pengumpulan data, nilai ulangan harian tentang Menulis Iklan Baris, rata-rata nilai yang didapat hanya sebesar 65,2 . Dari 30 siswa, hanya 10 siswa yang mendapat nilai di atas 70 . Ini berarti hanya $33,3 \%$ siswa yang telah mencapai ketuntasan belajar, karena Kriteria Ketuntasan Minimal (KKM) telah ditentukan sebesar 70.

Daftar frekuensi nilai ulangan harian Bahasa Indonesia Menulis Iklan Baris siswa Kelas IX A SMP Negeri Negeri 1 Besuki Kecamatan Besuki Tulungagung pada kondisi awal adalah 2 siswa atau 6.7\% yang mendapat nilai antara 0 - 40, ada 18 siswa atau $60.0 \%$ yang mendapat nilai antara 41 - 69, dan ada 10 siswa atau $33,3 \%$ yang mendapat nilai antara 70 - 100. Dengan ketentuan nilai KKM 70, maka dapat disimpulkan jika pencapaian prestasi nilai 70 - 100 yang hanya 33,3\% merupakan prestasi yang rendah.

Selain itu, dari proses wawancara diperoleh kesimpulan bahwa siswa kurang berminat dalam melaksanakan kegiatan pembelajaran, serta dalam pembelajaran Guru lebih sering menggunakan ceramah sehingga siswa merasa jenuh dan bosan, akibatnya minat siswa untuk belajar Bahasa Indonesia terutama pada Menulis Iklan Baris menjadi berkurang sehingga mempengaruhi hasil prestasinya

Berdasarkan hasil data yang dikumpulkan, dapat dikemukakan dua hal pokok yang perlu diatasi, yaitu menumbuhkan minat siswa untuk belajar Bahasa Indonesia dan memahamkan Menulis Iklan Baris dengan cara mengaktifkan siswa dalam kegiatan belajar mengajar dan meningkatkan Ketrampilan Menulis siswa dengan menerapkan Pendekatan Think Pair Share pada siklus 1 nanti dengan harapan 
Vol. 2 No. 2, April 2018;

Ketrampilan Menulis siswa dapat meningkat. Untuk itu perlu dilaksanakan perbaikan pembelajaran pada siklus 1 dan jika belum tuntas maka akan dilanjutkan pada siklus 2 .

Siklus 1 table berikut:

Berdasarkan penilaian Observasi Siklus 1 didapatkan hasil observasi pada

Tabel 1 Observasi Siklus 1

\begin{tabular}{|l|l|l|}
\hline No & Kegiatan Siswa & Prosentase \\
\hline 1 & Kelengkapan menyiapkan alat dan bahan percobaan & $60 \%$ \\
\hline 2 & $\begin{array}{l}\text { Keruntutan langkah-langkah dalam pelaksanaan kegiatan } \\
\text { percobaan }\end{array}$ & $65 \%$ \\
\hline 3 & Keaktifan siswa selama melaksanakan kegiatan percobaan & $70 \%$ \\
\hline 4 & Keaktifan siswa dalam mengutarakan pendapat saat berdiskusi & $68 \%$ \\
\hline 5 & Kesimpulan akhir sesuai percobaan & $66 \%$ \\
\hline
\end{tabular}

Adapun hasil post test siklus pertama adalah:

Tabel 2 Hasil Pos tes Siklus 1

\begin{tabular}{|l|l|l|}
\hline No & Deskripsi & Nilai \\
\hline 1 & Jumlah Nilai & 2195 \\
\hline 2 & Rata-rata Hasil Post Test & 73,2 \\
\hline 3 & Jumlah siswa yang mendapat nilai diatas KKM (70) & 19 \\
\hline 4 & Presentase siswa yang mendapat nilai diatas KKM (70) & $63,3 \%$ \\
\hline 5 & Jumlah siswa yang mendapat nilai dibawah KKM (70 & 11 \\
\hline 6 & Presentase siswa yang mendapat nilai dibawah KKM (70) & $36,7 \%$ \\
\hline
\end{tabular}

Dari tabel tersebut terdapat 11 siswa atau $36,7 \%$ yang mendapat nilai antara 41 - 69, dan 19 siswa atau 63,30\% yang mendapat nilai antara $70-100$. Dengan ketentuan nilai KKM 70, dapat disimpulkan jika pencapaian prestasi nilai $70-100$, maka prestasi belajar siswa telah meningkat dari 33,3\% menjadi $63,3 \%$. Namun karena belum mencapai target indicator pencapaian siklus I sebesar $85 \%$ atau lebih, maka akan dilanjutkan ke Siklus II.

Selain itu, dari proses wawancara diperoleh kesimpulan bahwa beberapa siswa menjadi bersemangat dalam belajar Bahasa Indonesia, karena pelaksanaan kegiatan belajar Bahasa Indonesia dengan Pendekatan Think Pair Share ini dilaksanakan dengan langsung secara mandiri oleh siswa, dan melaksanakan kegiatan bersama kelompok sehingga lebih ringan. Meskipun masih terdapat kendala-kendala seperti yang telah diuraikan dalam laporan observasi.

\section{Siklus II}

Adapun prosentase hasil observasi dalam pelaksanaan percobaan pada siklus II dapat dilihat dari tabel bawah ini:

Tabel 3 Observasi Siklus 2

\begin{tabular}{|l|l|l|}
\hline No & Kegiatan Siswa & Prosentase \\
\hline 1 & Kelengkapan menyiapkan alat dan bahan percobaan & $80 \%$ \\
\hline 2 & $\begin{array}{l}\text { Keruntutan langkah-langkah dalam pelaksanaan kegiatan } \\
\text { percobaan }\end{array}$ & $90 \%$ \\
\hline 3 & Keaktifan siswa selama melaksanakan kegiatan percobaan & $90 \%$ \\
\hline 4 & Keaktifan siswa dalam mengutarakan pendapat saat berdiskusi & $88 \%$ \\
\hline
\end{tabular}


Hasil post test pada siklus kedua dapat menjadi perhitungan persentase peningkatan Ketrampilan Menulis siswa. Dengan acuan penilaian tetap berdasarkan nilai KKM yang telah ditetapkan yaitu paling sedikit siswa memperoleh nilai 70 . Adapun rekapitulasi hasil test siklus II adalah sebagai berikut:

Tabel 4 Hasil Pos Tes Siklus 2

\begin{tabular}{|l|l|l|}
\hline No & Deskripsi & Nilai \\
\hline 1 & Jumlah Nilai & 2462 \\
\hline 2 & Rata-rata Hasil Post Test & 82,1 \\
\hline 3 & Jumlah siswa yang mendapat nilai diatas KKM (70) & 28 \\
\hline 4 & Presentase siswa yang mendapat nilai diatas KKM (70) & $93,3 \%$ \\
\hline 5 & Jumlah siswa yang mendapat nilai dibawah KKM (70 & 2 \\
\hline 6 & Presentase siswa yang mendapat nilai dibawah KKM (70) & $6,7 \%$ \\
\hline
\end{tabular}

Dari tabel di atas diketahui terdapat 2 siswa atau 6,7\% yang mendapat nilai antara 41 - 69, dan 28 siswa atau 93,3\% yang mendapat nilai antara 70 - 100 . Dengan ketentuan nilai KKM 70, dapat disimpulkan jika pencapaian prestasi nilai 70 100 , maka prestasi belajar siswa telah meningkat dari $60 \%$ menjadi $93,3 \%$. Dengan $93,3 \%$ maka telah tercapai indicator pencapaian siklus II sebesar yang $85 \%$ atau lebih, maka tidak perlu dilanjutkan ke Siklus III.

Selain itu, dari proses wawancara diperoleh kesimpulan bahwa beberapa siswa menjadi bersemangat dalam belajar Bahasa Indonesia, karena pelaksanaan kegiatan belajar Bahasa Indonesia dengan pendekatan Think Pair Share ini dilaksanakan dengan melibatkan masing-masing anggota kelompok, dan didiskusikan bersama kelompok sehingga mereka lebih rileks dan ringan dalam mengerjakan laporan kegiatan. Meskipun masih terdapat kendala-kendala seperti yang telah diuraikan dalam laporan observasi.

\section{PEMBAHASAN}

Berdasarkan hasil pelaksanaan pada siklus I, II dapat dinyatakan bahwa terjadi peningkatan kualitas pembelajaran yang tampak dan perolehan hasil evaluasi dan keaktifan siswa. Dari tabel 4.2 dan gambar 4.2 siklus I hasil observasi menunjukkan, prosentase keberhasilan kelengkapan menyiapkan alat dan bahan percobaan $60 \%$, prosentase keruntutan langkah-langkah yang ditempuh dalam pelaksanaan percobaan $65 \%$, prosentase keaktifan siswa dalam melaksanakan kegiatan percobaan $70 \%$, prosentase keaktifan siswa dalam mengutarakan pendapat saat berdiskusi $68 \%$ dan prosentase hasil penarikan kesimpulan akhir sesuai percobaan $66 \%$.

Berdasarkan tabel 4.5 dan gambar 4.4 siklus II hasil observasi menunjukkan, prosentase keberhasilan metode kelengkapan menyiapkan alat dan bahan percobaan siswa yang disiapkan $80 \%$, prosentase keruntutan langkah-langkah yang ditempuh dalam pelaksanaan percobaan $90 \%$, prosentase keaktifan siswa dalam melaksanakan kegiatan percobaan $90 \%$, prosentase keaktifan siswa dalam mengutarakan pendapat saat berdiskusi $88 \%$ dan prosentase hasil penarikan kesimpulan akhir sesuai percobaan $87 \%$.

Dari daftar nilai (lihat lampiran) dapat kita lihat adanya prosentase kenaikan nilai Bahasa Indonesia mulai dari kondisi awal pra tindakan, diketahui baru 10 siswa atau $33,3 \%$ yang mengalami ketuntasan belajar dan mendapatkan nilai sesuai dengan KKM. Hasil evaluasi siklus I menunjukkan baru 19 siswa atau 63,3\% yang mengalami ketuntasan belajar dan mendapat nilai sama dengan atau di atas KKM yaitu 70. Hal itu menunjukkan bahwa pelaksanaan siklus I belum mencapai keberhasilan, karena indicator pencapaian adalah sebesar $85 \%$ atau lebih. Siklus II menunjukkan ada 28 
siswa atau 93,3\% dari 30 siswa yang mengalami ketuntasan belajar. Sehingga peneliti menyimpulkan bahwa pada siklus II ini peneliti telah mencapai keberhasilan dari penelitian tindakan kelas yang telah dilakukan.

Ketika peneliti melaksanakan siklus I, peneliti mengalami berbagai kendala antara lain masih ada siswa yang kesulitan dalam membedakan antara puisi. Masih ada kelompok yang bingung dalam mengikuti langkah-langkah yang tertera dalam lembar kegiatan. Masih ada beberapa siswa yang belum aktif dalam pelaksanaan percobaan. Ketika pelaksanaan diskusi, ada beberapa siswa yang tidak aktif menyampaikan pendapatnya. Dalam menyimpulkan hasil percobaan, terdapat 4 (tiga) kelompok yang malu untuk presentasi, dan hanya terdapat 4 (empat) siswa yang mengajukan pertanyaan.

Peneliti kemudian melaksanakan siklus II sebagai perbaikan siklus I, sebelum pelaksanaan siklus II ini peneliti mengganti rencana pembelajaran Model Pembelajaran Metode Think pair share baru yaitu dengan menulis iklan baris untuk kegiatan sekolah. Dalam pelaksanaan percobaan, peneliti senantiasa memberi bimbingan untuk siswanya dalam melaksanakan langkah-langkah sesuai lembar kegiatan. Peneliti pun memberi bimbingan siswa saat berdiskusi untuk menarik kesimpulan.

Dengan adanya motivasi guru berupa reward, siswa telah terlihat aktif dalam kegiatan pembelajaran dalam melaksanakan percobaan, presentasi di depan kelas dan berdiskusi menarik kesimpulan. Meskipun ada kendala yaitu ada beberapa siswa yang masih belum menggunakan kalimat yang baku untuk menulis iklan baris sehingga suasana menjadi gaduh, namun dengan hasil prestasi belajar yang dicapai dapat disimpulkan bahwa penelitian tindakan kelas dari siklus II ini telah berhasil.

Dalam setiap pelaksanaan siklus terdiri dari 4 (empat) tahapan, yaitu perencanaan tindakan, pelaksanaan, observasi, dan refleksi, kegiatan ini dilaksanakan berdaur ulang. Sebelum melaksanakan tindakan dalam tahap siklus, perlu perencanaan. Perencanaan ini memperhatikan setiap perubahan yang dicapai pada siklus sebelumnya terutama pada setiap tindakan yang dapat meningkatkan Ketrampilan Menulis siswa. Hal ini didasarkan pada analisis perkembangan dari pra siklus, siklus I sampai siklus II. prosentase kenaikan nilai Bahasa Indonesia siswa Kelas IX A dari pra siklus, siklus I sampai Siklus II. Pada pra siklus, siswa yang mendapat nilai minimal 70 ada 10 siswa atau 33,3\%, pada siklus I siswa yang mendapat nilai minimal 70 ada 19 siswa atau 63,3\%, pada siklus II siswa yang mendapat nilai minimal 70 ada 28 siswa atau 93,3\% dari 30 siswa. Dari pra siklus kemudian dilaksanakan siklus I prestasi siswa mengalami prosentase kenaikan 30,0\%. Dan dari siklus I kemudian dilaksanakan siklus II prestasi siswa mengalami prosentase kenaikan 30,0\%.

\section{KESIMPULAN}

Penerapan pendekatan Think Pair Share dapat meningkatkan Ketrampilan Menulis Bahasa Indonesia siswa Kelas IX A SMP Negeri 1 Besuki Kecamatan Besuki Kabupaten Tulungagung. Terjadi perubahan kenaikan prosentase dalam menyiapkan alat dan bahan, keruntutan langkah-langkah siswa dalam melaksanakan percobaan, keaktifan siswa dalam melaksanakan kegiatan percobaan, keaktifan siswa ketika berdiskusi dan hasil akhir atau simpulan yang diperoleh dari hasil kegiatan diskusi

\section{SARAN}

Berikut saran yang dapat diajukan berkaitan dengan penelitian ini, untuk melaksanakan pengembangan pembelajaran menggunakan pendekatan Think Pair Share memerlukan persiapan yang cukup matang, sehingga guru harus mampu menentukan atau memilih topik yang benar-benar bisa dikembangkan dengan Pengembangan Pembelajaran menggunakan pendekatan Think Pair Share dalam proses belajar mengajar sehingga memperoleh hasil yang optimal. Dalam rangka meningkatkan kualitas kinerja Guru, guru hendaknya lebih sering melatih Guru dengan berbagai pendekatan pengajaran, walau dalam taraf yang sederhana, dimana Guru 
nantinya dapat menemukan pengetahuan baru, memperoleh konsep dan keterampilan, sehingga Guru berhasil atau mampu memecahkan masalah-masalah yang dihadapi. Perlu adanya penelitian yang lebih lanjut, karena hasil penelitian ini hanya dilakukan di SMP Negeri 1 Besuki semester 1 tahun pelajaran 2015/2016, dan untuk peneltian yang serupa hendaknya dilakukan perbaikan-perbaikan agar diperoleh hasil yang lebih baik.

\section{DAFTAR RUJUKAN}

Buchori, M. 1992. Psikologi Pendidikan 3. Bandung: Jeanmars.

Fudyartanto, Ki RBS. 2002. Psikologi Pendidikan dengan Pendekatan Baru. Yogyakarta: Global Pustaka IImu.

Gulo. W. 2004. Strategi Belajar Mengajar. Jakarta: PT. Grasindo.

Gunter. 1999. Games for Children. London: Oxford University Press.

Hamalik, O. 2003. Kurikulum dan Pembelajaran. Jakarta: Bumi Aksara.

Hamalik, O. 2004. Proses Belajar Mengajar. Jakarta: Bumi Aksara.

Hartina. 2008. Pengaruh Model Pembelajaran Kooperatif Tipe Think Paire Share (Think Pair Share) terhadap Hasil Belajar Kimia Siswa Kelas XI IPA SMA Negeri 5 Makassar (Studi pada Materi Pokok Laju Reaksi). Skripsi tidak diterbitkan. Makasar: Jurusan Kimia FMIPA, UNM.

Hayinah. 1992. Masalah Belajar, Malang: IKIP Negri Malang.

Ibrahim, dkk. 2000. Pembelajaran Kooperatif. Surabaya: University Press.

Lie, Anita. 2002. Cooperatif Learning. Jakarta: PT. Gramedia.

Makmun, A.S. 2003. Psikologi Pendidikan. Bandung: PT Rosda Karya Remaja.

Nasution, S. 1996. Azas-azas Mengajar. Bandung: Tarsito.

Slavin, R. E. 1994. Educational Psychology Theory Into Practices. 4th ed. Boston: Ally and Bacon Publishers.

Sudjana, N., \& Ibrahim. 1989. Penelitian dan Penilaian Pendidikan. Bandung: Sinar Baru.

Syah, M. 2003. Psikologi Belajar. Jakarta: PT. Raja Grafindo Persada

Tirtonegoro, S. 1988. Anak Supernormal dan Program Pendidikannya. Yogyakarta: Bumi Aksara.

Winkel, W.S. 2004. Psikologi Pengajaran. Yogyakarta: Media Abadi. 